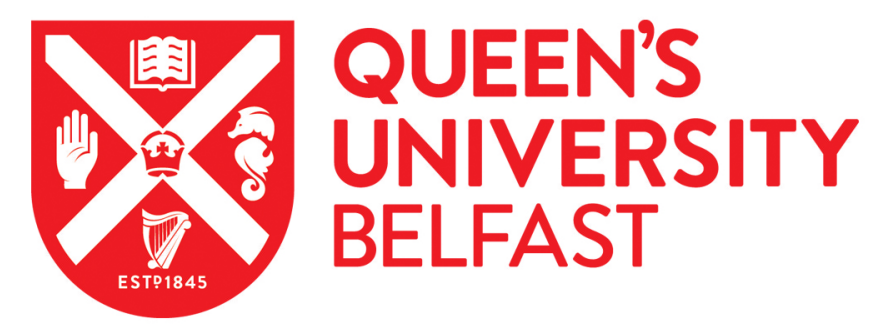

\title{
'Complex' Crime Fiction and the Politics of Ongoing-ness: Don Winslow's War against Endings
}

Pepper, A. (2020). 'Complex' Crime Fiction and the Politics of Ongoing-ness: Don Winslow's War against Endings. Crime Fiction Studies, 1(1).

Published in:

Crime Fiction Studies

Document Version:

Peer reviewed version

Queen's University Belfast - Research Portal:

Link to publication record in Queen's University Belfast Research Portal

Publisher rights

(c) 2020 Edinburgh University Press.

This work is made available online in accordance with the publisher's policies. Please refer to any applicable terms of use of the publisher.

\section{General rights}

Copyright for the publications made accessible via the Queen's University Belfast Research Portal is retained by the author(s) and / or other copyright owners and it is a condition of accessing these publications that users recognise and abide by the legal requirements associated with these rights.

Take down policy

The Research Portal is Queen's institutional repository that provides access to Queen's research output. Every effort has been made to ensure that content in the Research Portal does not infringe any person's rights, or applicable UK laws. If you discover content in the Research Portal that you believe breaches copyright or violates any law, please contact openaccess@qub.ac.uk. 


\title{
'Complex' Crime Fiction and the Politics of Ongoing-ness:
}

\section{Don Winslow's War against Endings}

\section{Andrew Pepper, Queen's University Belfast, a.pepper@qub.ac.uk}

\begin{abstract}
:
In pointing out that beginnings and endings merge in Don Winslow's 'drug war' trilogy - The Power of the Dog (2005), The Cartel (2015), and The Border (2019) - I argue that his narratives, like the 'war on drugs' itself, are 'ongoing.' Taking the resulting tension whereby this open-endedness or ongoing-ness is set against crime fiction's more typical generic push to resolution, as a starting point, I use and develop Mittell's concept of 'complex TV' to account for the complexities and continuities of Winslow's fiction. In one sense, this ongoingness is occasioned by Winslow's subject matter: it is the sociopolitical realities of the 'war on drugs' which determine the trilogy's structural and generic qualities. But what makes Winslow such an important writer are the particular ways he reshapes and pushes against the limits of narrative and genre, something that is made possible by and in turn makes possible a particular understanding of political struggle as ongoing and irresolvable. In my essay I explore the political implications of Winslow's fiction through a close examination of narrative and genre and where the emphasis is placed on breakdown and glitch rather than the successful realisation of totality.
\end{abstract}

Keywords: crime fiction, war on drugs, Don Winslow, narrative, genre, cognitive mapping, ongoing-ness.

\section{Bio:}

Andrew Pepper is Senior Lecturer in English at Queen's University Belfast. He is the author of Unwilling Executioner: Crime Fiction and the State (OUP 2016) and The Contemporary American Crime Novel: Race, Ethnicity, Gender, Class (EUP 2000) and the co-editor of Globalization and the State in Contemporary American Crime Fiction (Palgrave 2016). He is also one of the co-editors of the forthcoming Routledge Companion to Crime Fiction. He has written a series of crime novels set in nineteenth-century Britain and Ireland including The Last Days of Newgate (2006) and Bloody Winter (2011), all published by Weidenfeld \& Nicolson. 


\section{'Complex' Crime Fiction and the Politics of Ongoing-ness: \\ Don Winslow's War against Endings}

It is no coincidence that the three novels of Don Winslow's 'war on drugs' trilogy - The Power of the Dog (2005), The Cartel (2015), and The Border (2019) - begin and end in approximately the same manner. The beginning of The Cartel frames the problem of the 'war on drugs' as ongoing: 'The so-called war on drugs is a revolving door - you take one guy out, someone else grabs the empty chair at the head of the table. It will never change, as long as the insatiable appetite for drugs is here' (2015: 20). Which is an echo of the ending of The Power of the Dog where we are told, '[t]he drugs stopped flowing out of Mexico for about fifteen minutes after [Adán Barrera's] downfall, then new kids on the block stepped into his place. There are more drugs coming into the country than ever' (2006: 542). But it also looks ahead to the beginning of The Border where the same argument is reframed: 'Barrera's death didn't slow down the flow for even a week. There's more coming in now than ever' (2019: 64). It is no coincidence because the subject of the Winslow's trilogy - the US's doomed efforts to stem the flow of illegal narcotics across its southern border, like the 'war on drugs' itself - has no obvious end-point and so, narratively speaking, beginnings and endings inevitably merge. But Winslow is also a writer of crime fiction, even if this designation gives him considerable generic latitude, given he might also be characterized as a thriller or espionage or even war novelist. As such, his novels must conform, in some degree, to what we, as readers, expect genre fiction to do, however loosely this term is defined. The first two novels, for example, are structured around the long struggle between Art Keller, of the Drug Enforcement Agency, and Adán Barrera, who rises to become head of the Sinaloan cartel, and 
where the first novel, The Power of the Dog, culminates with Barrera's capture and arrest and the second, The Cartel, with his assassination by Keller in an act of extra-legal revenge.

This essay takes this tension between a generic imperative towards resolution (e.g. where the 'bad' Mexican drug trafficker is, first, arrested and then killed by the 'good' US DEA agent) and the ongoingness and complexity of the problem of the 'war on drugs' - where beginnings are reframed as endings and vice versa and where no one is unequivocally 'good' or 'bad' - as its starting point. In doing so, it reframes Winslow's 'drug war' trilogy as 'complex' crime fiction, following Jason Mittell's description of long-form serial television series like The Wire and Breaking Bad as 'complex TV' - based first and foremost upon claims about their 'narrative complexity' (2015: 17) and their 'absolute and deliberate failure, or more accurately, refusal' to resolve their stories in straightforward ways (2015: 335). One could say, of course, that much, if not all, crime fiction is complex in its own way - even in the case of Agatha Christie, the doyenne of reassuring or 'cozy' mysteries, and her most famous novel, The Murder of Roger Ackroyd (1926), where, as Bayard has argued, Christie's preferred account of the murder and murderer is at odds with who may have been responsible (Bayard, 2000). But I am using term very deliberately, following Mittell, to demarcate those (narrative and generic) features which Winsow's drug war fiction shares with long-form serial TV shows like The Wire: a geographical and geopolitical expansiveness, a generic restlessness (i.e. moving across and between different generic forms), multiple, interlocking storylines involving a vast cast of characters, a clear socio-political framework, and a willingness to undercut a more typical narrative push towards order and resolution.

The claim that narrative fiction eludes or resists closure in any straightforward sense is not especially new or revealing. D.A. Miller, for example, argues it is 'not that novels do not "build" toward closure, but that they are never fully or finally governed by it' (1981: xiv) - i.e. no closure can 'fully extinguish the various energies driving the narratable' (Reising 1990: 8). 
Following Miller, Russell Reising points out that the 'concluding moments' or 'loose ends' in a series of nineteenth- and early twentieth-century US texts not only fail to resolve or conclude important narrative issues, but exacerbate, problematize, and sometimes explode exactly the issues which generate the narrative' (1990: ix). With respect to crime fiction, which has traditionally been seen as the end-orientated genre - i.e. where the events of the narrative are necessarily brought to order by the orchestrating figure of the investigator - Gulddal, King and Rolls, with half an eye on Bayard, argue that the open form of 'the crime fiction structure' (where anything could feasibly happen) 'redirects attention away from the finality of the solution towards the dynamics of the investigation' (forthcoming). In this essay, I am less interested in the 'loose ends' that accrue from unresolved or unresolvable dramas and what this tells us about the impossibility of endings than in the political implications of Winslow's generic restlessness and narrative open-endedness, i.e. where nothing is or can ever be fully resolved. In part, of course, this ongoing-ness is occasioned by Winslow's subject matter: it is the sociopolitical realities of the 'war on drugs' which determine the trilogy's structural and generic qualities. However, what makes Winslow such an important writer are the particular ways he reshapes and pushes against the limits of narrative and genre, something that is made possible by and in turn makes possible a particular understanding of politics. Vis-à-vis an Arendtian understanding of politics as engagement, argument, and debate, and a Marxian account of fundamentally clashing tribes or classes, Winslow's novels, which at once gesture toward some kind of totalising vision and yet show us that we cannot know or see everything, at least not at the same time, and which position his subjects in relation to political circumstances where no end-point is ever possible, come closer to Giorgio Agamben's conception of politics in Means Without End: '[p]olitics that is the sphere neither of an end in itself nor of means subordinated to an end' (2000: 116). 
For Agamben, there is the tendency or temptation to reduce all contemporary life, especially in the Global South, to the violence produced by a particular iteration of sovereignty as the exception (1998: 180) - which becomes, as Frazer and Hutchings note, 'the predominant mode in which politics is conducted' (2011: 132). The ongoing-ness of the 'war on drugs' and its ties to both the execution of sovereign power and the subsumption of life to the dictates of the market produces a particular kind of bleak narrative where death, violence and failure are presented as inevitable: as Winslow puts it, the 'war on drugs' as an 'obscene absurdity' or 'absurd obscenity' (2006: 492). But Agamben's account of ongoing-ness in Means without End holds open the possibility of a more agonistic and irresolvable but also perhaps more hopeful politics, e.g. without violence and where politics 'is the sphere of a pure mediality without end intended as the field of human action' (2000: 116). In the first part of my essay, I read Winslow's 'complex' crime fiction, which forges connections between individual characters in terms of their place in larger organisational systems (law enforcement, trafficking cartels etc.), in light of Fredric Jameson's notion of 'cognitive mapping.' By focusing on characters that do not easily fit into the master-narrative of drug war fiction, I look for the ways in which Winslow's novels put pressure on Jameson's presumption that the constituent parts can be made to 'designate the absent, unrepresentable totality' (1995: 10). In doing so, I consider how or whether the ongoing-ness of individual stories might constitute some kind of 'glitch' vis-a-vis a larger narrative about sovereignty, violence and the exception. In the second part, I use the resulting notion of breakdown and Lauren Berlant's understanding of the 'waning of genre' in the face of new social realities to think about the particular generic formulations at work in Winslow's novels. By situating these 'complex' novels as generic hybrids, drawing upon the dissident energies of various genres and forms (e.g. crime, detective, spy, thriller, war), I tease out the political implications of this hybridisation and the emergence of what I term drug war fiction as a 
means for thinking, more hopefully, about what might exist beyond or outside of Agamben's violence of the exception: i.e. 'the moment of exception, in which politics is constituted through sovereign exclusion of life' (Frazer and Hutchings, 2011: 132).

\section{The politics of narrative: glitches in the system}

There are two characters who stand out in The Cartel and The Border respectively; that is, they stand out because their stories do not seem to easily fit into Winslow's ostensible masternarrative which pits Art Keller of the DEA against high-level drug traffickers who belong to

one or other of the main Mexican cartels. The first is Jesus 'Chuy' Barajos, an eleven-year old child when he is first introduced to us, from New Laredo, Texas, who becomes entangled with the Zetas and is brutalised by their training methods and who later on, having run away from the Zetas and befriended a Guatemalan refugee, Flor, witnesses her murder at the hands of the Zetas and joins forces with a rival cartel to practice the brutality he's been taught on five Zetas 'peces gordos - big bosses' (2015: 197). His decision to behead the five men and roll their heads across the dancefloor of a Michoacán club is one of the novel's more outré or excessive acts of violence and is based on an event which actually took place in Uruapan, Michoacán, in September 2006. By devoting fifty pages to Chuy's unfolding story, Winslow allows us to see him not simply as monster or 'endriago' killer, a figure who, in Valencia's terms, 'contradict(s) the logic of what is acceptable because of their new awareness that they have become redundant in the economic order' (2018: 27). In Chuy's case, there is little consciousness in his actions and certainly no 'awareness that [he has] become redundant in the economic order'. Rather he moves uneasily and problematically between the position of victim and perpetrator, a damaged child who is largely unaware of the ways he acts and is acted upon. Later, in The Cartel, Chuy is sequestered back into the Zetas following an initiation ritual where he has to kill another passenger from the bus they've been removed 
from at gunpoint or be killed himself. Thereafter Chuy commits further murders in service of the Zetas, including that of Erika (a brave woman who has volunteered as the police chief in a small town in the Juárez Valley) and is found at the end of the novel by Keller, having flayed and beheaded 'Forty,' a Zetas' boss, kicking a football with 'Forty's skinned face stitched across it' (2015: 609). In the novel's epilogue we are told that he 'would probably never recover from the sort of traumas that he'd experienced [and] that the best they could hope for would be a kind of base functionality, a twilight existence' (2015: 615).

Chuy's story has no clear 'arc' in any conventional sense. There is nothing that he learns or gains insight into and he does not undergo any gradual or immediate conversion, either in a moral sense (e.g. from bad to good or vice versa) or in a strategic sense (e.g. moving from one side to another). His is not a cautionary tale, even though it is hard to imagine that anyone would wish to see the world as he does or act in the ways he does. Chuy is not a victim in any straightforward sense, though what he witnesses ('Fifty-gallon barrels are set outside, and every few minutes a body - dead or still barely alive - is shoved into a barrel and lit on fire') is clearly traumatising: Chuy, we are told, in relation to this, 'will never forget the sound. Never get the smell out of his nose' (2015: 497). As readers, we may see his violence in the context of the brutalities practiced against him, but we are not permitted to feel sorry for him because he exacts violence at the unsullied and heroic like Erika as well as against ostensibly more deserving targets like 'Forty'. Nor is he someone we can admire because most of the time he seems unaware of what he is doing and why is he doing it. As someone who is described by Keller as 'Catatonic' and 'Insane' and a 'Monster [...] with flat, dull eyes' (2015: 609), Chuy is trapped between in a role between victim and victimiser, a liminal space from which the novel cannot free him, even at the end. The narrative, then, is a patchwork of these fragments - a thread that loosely connects the horrific acts that Chuy perpetrates and witnesses to the violence which is acted upon him. The portrait is neither 
complete nor totalising - hence my wider claim about narrative complexity and ongoing-ness: we are not asked to judge or perhaps even understand. While he may be a 'Monster' in Keller's description, he is also someone who needs long-term care. Moreover Chuy's narrative, at least in The Cartel, is not resolved in such a way as to give us clear answers beyond the selfevident truth that Chuy's 'traumas stopped his growth when they started' (2015: 615). In my reading, Chuy constitutes a glitch in the system - not merely someone who does not fit per se but rather a figure who, in light of Lauren Berlant's definition, is 'the revelation of an infrastructural failure' (2016: 393): i.e. where the failure, both personal and systemic, is irresolvable in the context of the wider narrative.

Chuy returns in The Border, initially as guest and patient in the home of Keller and his wife, Marisol, and then having left without reason or explanation, turns up in the middle of the hijacking of a public bus by students at the Ayotzinapa Rural Teachers' College in order to attend a rally in Mexico City. The wider point, if there is a point, is either that Chuy is unlucky, plain and simple, or that nowhere in Mexico or throughout the Americas is beyond the domain of the cartels. The hijacked bus is carrying cartel heroin, unbeknown to the students and indeed Chuy, who are then massacred in order to retrieve the drugs and cover up the crime. There is nothing cathartic about his death and no one, not even the reader, is allowed to mourn for him. The more significant revelation is saved for the concluding paragraph of the chapter. 'The heroin from the bus arrives at a mill in New York, where Darius Darnell breaks it down into dime bags. Some of it ends up in the arm of Jacqui Davis' (2019: 224).

This revelation is significant because it demonstrates how drugs, in this case heroin, act as a stand in for, or supplement to, narrative itself; that is, a way of connecting and even ordering disparate people and events across time and space. To illustrate this claim, I want to turn to the second character who does easily not fit into the master-narrative of the drug wars 
with its attendant and totalising violence; Nico Ramírez is another child, ten years old, and a collector of rubbish in Guatemala City who is forced to flee his home in order to escape being assimilated into a drug gang, Calle 18, and who travels north as an 'illegal' on 'El Tren Devorador' - "The Train that Devours"; El Tren de Desconocidos - "The Train of the Unknowns"; El Tren de la Muerte - "The Train of Death"' (2019: 336). The train takes Nico through Mexico before he tries to cross the border into the US and is caught and sent to the Virginia Youth Detention Facility, before eventually being released into the care of his aunt and uncle in New York. Nico's story is not incidental to the larger narrative nor is it skimmed over for the purposes of narrative efficiency. Winslow gives himself seventy pages to detail the ups and downs of Nico's journey from Guatemala City to New York and a further thirty pages to show us how Nico, perhaps inevitably, is assimilated into a US branch or cell of Calle 18, the same gang he risked his life trying to evade in Guatemala City. Perhaps inevitably, too, at least in a narrative sense, Calle 18 are responsible for distributing the same heroin delivered in bulk from Mexico to Darius Darnell and sold in 'dime bags' to Jacqui Davis, both of whom play significant parts in the unfolding narrative of The Border.

In telling this kind of open-ended story, in which links between disparate players from the interconnected realms of trafficking, finance, interdiction, and government assume narrative and geographical or indeed geopolitical form, we can start to see an emerging political project; i.e. where a particular narrative form presupposes a particular kind of politics and vice versa. In the case of The Border, Winslow's attempts to render the totality of connections between disparate players across global spaces and national jurisdictions has important political and disciplinary ramifications. In one sense, of course, to narrativize the drug wars is to recognise the global dimension of the drug business - i.e. how the 'geographical expansion, spatial re-organization, and uneven capitalist development' (Harvey, 
2011: 23) that is implicit to the drug trade as system produces a map of what we might call the winners and losers of capital accumulation.

In another sense, the linkage between production and consumption is reimagined in The Border as a 'top-down/bottom-up strategy' in which an undercover cop Bobby Cirello 'would be sent out to penetrate the New York heroin connection from the lowest level and work his way up' and Keller and his team 'would try to find an opening at the top of the financial world and work their way toward a connection between the two' (2019: 137). At the same time Winslow shows us the linkages between 'the rayadores' who 'make thirty or forty dollars a day' cultivating the opium from poppies in rural Guerreros (2019: 117) to the 'middlemen' who process the opium paste into 'cinnamon heroin' after which it is 'loaded onto buses for what's called "shotgun shipping" north' (2019: 118) to Darius Darnell who receives the heroin shipments in New York and 'breaks it down into dime bags' and finally to those at the top of the Mexican cartels like Caro Rafael and Eddie Ruiz who must accumulate and then lauder the profits of their enterprise. As such, a narrative map plotting the various connections between top and bottom, US and Mexico, and production and consumption, begins to take shape. Cirello makes contact with Jacqui Davis who has 'the heart and soul of an addict, because she loves it, loves the H, loves the high' (2019: 133) and through her locates her supplier, Marco, and above him, DeStefano, a lower level mob figure, to whom Cirello sells his services as a corrupt cop, whereupon, after proving his usefulness, he is eventually sequestered into the services of mid-level distributor, Darius Darnell. Meanwhile, Keller and Hugo Hidalgo try to work out 'how drug money makes its way through the banking system' (2019: 141) by going after Chandler Claiborne, a syndication broker with the Berkeley Group - 'a hedge fund' with a 'controlling interest in some of the largest office and residential buildings in the world' (2019: 139) including Park Towers, a 'high-rise building of offices, shops and condominiums in lower Manhattan' bought by the Terra Company using 'high- 
interest loans' which it is struggling to service - hence Claiborne is brought in to help put together a syndicate of investors to help meet 'the bubble payment' (2019: 237). These investors include HBMX, 'a private investment bank that's a major money launderer for the Sinaloa cartel' (2019: 237). The Terra Company is part owned by Jason Lerner, the son-in-law of presidential candidate (and soon to be president) John Dennison who, in an obvious reference to Trump, declares his candidacy for the presidency by announcing 'I'm going to build a great wall along the Mexican border' (2019: 306). The 'top down/bottom up strategy comes together in the form of a meeting in New York between Lerner, Claiborne and Echeverría of HBMX for which Cirello, via Darnell, provides the security and which is wiretapped by Keller - and where vague promises are made by Lerner to Echeverría. 'I can't promise that our connections would or would not take any specific actions,' Lerner says, 'But you will always find an ear' - to which Keller, who is listening to the exchange, reaches the following conclusion. 'My God. If John Dennison wins the election - The cartel has just bought the White House' (2019: 408).

There are a number of important political ramifications of this move to connect supply and demand, top and bottom, US and Mexico. For a start, it disrupts the conventional narrative of the drug wars which pits 'a handful of upstanding state officials ("the goodies")' and typically belonging to one of the US law enforcement agencies - against 'an array of traffickers and corrupt politicians ("the baddies")' - usually depicted as Mexicans (Pansters, 2018: 45). The expansive geographical and geopolitical frame also exposes the limits of nation-centered approaches to understanding and analysing textual fields (see Dimock and Buell, 2007: 1). Likewise, attempts to render the problems and complexities of the drug trade and narco-accumulation solely from a Latin American perspective cannot fully see or discern the complex relations between supply and demand-side economics that produces and sustains accumulative practices or indeed how the extreme violence wrought upon local populations in 
places like Juárez, Mexico and throughout the Global South is tied to 'the demands and requirements exported from the economic centers' (Valencia, 2018: 10). Here, only a Hemispheric or a global American Studies can begin to map and interrogate the complex relations between North and South and between what Ybarra-Frausto sees as the 'Latinization' of the United States and the 'North Americanization' of Latin America, so that are both are implicated in 'capitalism's structural logic of inequality' which is 'neither random nor accidental' and where 'development at one pole' is directly related to 'underdevelopment at another' (see Dowdy, 2013: 4-5).

If narrative - the narrative links between North and South/bottom and top/demand and supply - constitutes the most significant way of stitching these disparate elements together, the danger is that we see the kind of complex, open-ended, serial narratives of Winslow's trilogy and indeed The Wire as totalising. In other words, to evoke Jameson's notion of 'cognitive mapping,' how 'a situational representation on the part of the individual subject' might be implicated in 'that vaster and properly unrepresentable totality which is the ensemble of society's structures as a whole' (1992: 51). For Kinkle and Toscano, following Jameson, The Wire, notably in the second season, allows us to discern the contours of global capitalism which would otherwise be hidden and see, through narrative, how the apparently seamless or invisible commodity-chains of circulation can be prized apart to reveal real human suffering (2015). Kraniauskas, however, notes that while The Wire's 'narrative loops' connects the 'cycle of capital accumulation as it passes through commodity exchange, which takes place in the streets...to the cycles of finance and capital investment, which take place mainly in offices...the narrative pursuit of money through the cycle...of accumulation from the street into finance only goes so far, and this narrative limit constitutes the generic limit of The Wire as a work of crime fiction' (2012: 181). 
Kraniauskas's intervention is important because it draws attention to the limits of crime fiction's capacities to map totalising systems, even in the case of The Cartel or The Border where the geographical and geopolitical lens is considerably wider even than The Wire's. There may be instructive ways in which 'narrative loops' reveal not the smooth running of cycles of capitalism accumulation but rather their breakdown - i.e. where the breakdown or collapse in one aspect of capital accumulation leads to the breakdown or collapse in another aspect. More significant, from my point of view, is the extent to which figures like Chuy and Nico constitute glitches in the narrative convergence between top and bottom. For Berlant, as indicated earlier, a 'glitch is an interruption within a transition, a troubled transition. A glitch is also the revelation of an infrastructural failure' (2016: 393). In the way I am using the term here, these 'minor' figures constitute narrative glitches insofar as they direct our attention away from the larger dictates of structural violence and the state of exception and toward what is contingent and irresolvable. In other words, we are compelled to think about the ongoing-ness of life, despite the fact that 'the state of exception is the rule [and] that 'naked life is immediately the carrier of the sovereign nexus' (Agamben, 2000: 112).

Nico's unfolding story in The Border is especially instructive. In one sense, his signifying role is self-evident: as slum dweller and rubbish collector in Guatemala City, migrant across Mexico, asylum seeker in Virginia and low-level drug dealer in New York, he belongs to the 'bottom' domain and as such is very much acted upon by the deterministic forces of capital, ethnicity, class and nationality. However, as the cumulative details of his story add up over a hundred or more pages of the larger narrative, his status as determined, as $\operatorname{cog}$ in the system, starts to fray. His life may well be overdetermined by the horrific circumstances of the Guatemalan Civil War but just as significant are the countless smaller incidents that Winslow gives us: Nico and his friend Flor finding a chain ('thin, delicate, but 
it looks like gold') amidst a rubbish dump known as 'Canyon of the Dead' and selling it for 'twelve quetzals' (2019: 333); stowing away on top of a train with 'nothing much to do but look at the scenery and talk and hold on when the track dips one way or the other, or duck when branches are coming up' (2019: 339); seeing night stars '[f]or the first time in his life' (2019: 340); scavenging for food and evading the migra that 'patrol the areas around the tracks, looking for migrants' (2019: 347); playing 'checkers' in the 'dayroom' of the Southern Virginia Youth Detention Facility on tables 'bolted to the floor' and where even 'the checkboard is set into the table so it can't be used as a weapon' (2019: 505); and to the 'jerkoff' competition he and a friend oversee in the facility in order to win 'candy bars, bags of chips, sodas' (2019: 520). It is in and through these details that the whole temporarily disappears and in its place we see only glimpses and fragments: the raw, un-distilled 'facts' of Nico's existence do not in the end gesture towards anything more significant than what they are in and of themselves. These may well be chronologically arranged into what we might call story but the place of these loosely related smaller incidents in a much larger narrative about connectivity across time and space is much harder to discern - to the point where the 'here and now' cannot be made to 'express and designate the absent, unrepresentable totality' (Jameson, 1995: 10) and where the signifying potential of these individual stories, which are better understood as glitches in the narrative, starts to break down. ${ }^{1}$

\section{The politics of genre: the crime/war nexus}

In the case of Winslow's fiction, it is hard to separate the politics of genre from the politics of narrative - and indeed to separate both from the politics of the 'war on drugs'. What links these related domains is the idea of open-endedness or ongoing-ness; that is, of something not coming to an end. The closed narrative form, of which the detective novel is an example, suggests that 'the accrued significance of a story can only be fully realized in its resolution' 
(DeFino, 2014: 100), i.e. at the point where the detective offers the solution to the mystery and brings the narrative to order. In the case of Winslow's 'complex' crime fiction and the wider 'war on drugs' that his work thematises and interrogates, there is no hope or possibility of resolution. The moment that one cartel is dismantled or a leader put in prison or executed, another steps into their place. From a narrow enforcement and interdiction perspective, this continuity constitutes failure but insofar as the practices of the cartels are folded into the wider operations of capital, and by implications of the US and Mexican states as supporters and advocates of the expansion of capitalism into new territories, the political implications require further teasing out.

There are two ways of understanding this ongoing-ness in relation to the particularities of drug war violence. The first is to see the cyclical pattern of the violence - and the iterations of this violence in all three of Winslow's novels - as representing something that is fixed or stuck. Hence the framing of this 'unspeakable war' at the start of The Border in the following terms: 'there has been - in the pop-speak of the day - no "closure." No victory or defeat. No reconciliation or war crimes tribunals...Just a slow, sodden lessening of the violence' (2019: 23). Nothing very much changes from book to book, then: the violence spikes and lessens but the underlying logic (of supply and demand; of territorial acquisition and violent competition etc.) remains the same. The second way is to see this ongoing-ness not as an example of stasis or being 'stuck' but rather the opposite: that is, as something mobile, fractious and generally more unsettling of traditional modes of perceiving the world and of traditional genre or genres. This is not quite the same as equating the open-endedness of The Cartel, for example, with 'realism' even if 'real-life' - as it is represented in 'complex' TV and fiction - 'is filled with loose ends' (DeFino, 2014: 100). Rather it is an acknowledgement that the ongoing problems caused by drugs (e.g. violence, over-accumulation, addiction etc.) require new forms of representation to trace and interrogate their multiple, overlapping aspects. As a 
genre, we might say that crime fiction, with its narrative focus on investigation and revelation, provides what Berlant calls 'an affective expectation of the experience of watching something unfold' (2012: 6), albeit with a sense that things will be brought to some kind of order. In the same way, what Berlant calls 'the waning of genre' - or the mutability of traditional genre forms in the face of the structural transformations of our world - 'frames different kinds of potential openings within and beyond the impasse of adjustment that constant crisis produces' (2012: 6-7). ${ }^{2}$ To apply this to the context of Winslow's novels and the larger 'problem' of the war on drugs, the difficulty of generic categorisation is linked to a wider set of economic and geopolitical transformations that the works are seeking to interrogate. In Berlant's terms, the hybridisation of genre in the face of what she calls 'crisis ordinariness' - which speaks very well to the context of the ongoing drug wars where spectacular violence has become routine and even banal - is tied to the same working out of ambivalence that we saw in the example of Chuy (e.g. where there are no moral lessons or straightforward answers) and hence to Winslow's novels as examples of what I am calling 'complex' crime fiction.

There are a number of ways that Winslow's novels seek to push against their generic designation as US crime fiction and hence against the putative norms of what, in geopolitical terms, has been seen as an ideologically conservative form - i.e. where US territorial, economic and above all moral interests are affirmed (Holloway, 2008). The first two novels of the trilogy - The Power of the Dog and The Cartel - are structured around the long struggle between Keller and Mexican narco-boss Adán Barrera where one might be expected to root for the latter over the former. However, what Winslow does over the course of the two novels is show us how Keller and Barrera, at times arch-enemies, are also beneficiaries, key players and uneasy allies in the socio-economic expansion of capitalism into new territories (Paley, 2014). In doing so he shows us how the yoking together of military (state) power and the forces of capital accumulation and hence the 'differentiated links and exchanges' between 'the 
machine of global capital' and 'the war machine, the police machine, the criminal machine' produce 'a complex, interconnected spectrum of procedures for exploiting material and human resources' (Rodríguez, 2012: 9-11). In The Power of the Dog, Keller's obsessive quest to punish Barrera for his role in the torture and murder of DEA officer Ernie Hidalgo is complicated by the alliance Barrera has struck with higher-up figures in the Pentagon and CIA to fund and support 'the Contra drugs-for-arms operation' and the 'sponsored assassinations of left-wing figures in Latin America' (2005: 502). US intervention in The Cartel occurs when the violence threatens the long-term stability of the capitalist economy, notably oil extraction in Mexico (2015: 514), at which point Barrera is seen as the preferred partner because he brings 'peace and stability' (2015: 514). In both instances, the calculations are tied to what Mbembe would call a 'necropolitical' determination about 'who may live and who must die' (2003: 11-12), where the latter, overwhelmingly, are 'poor and working people and migrants' (Paley, 2014: 34). As Winslow puts it, 'This is not a war on drugs. It is a war on the poor' (2015: 582). If 'pillage, profit and plunder have been the mainstays of war since precolonial times' (Paley, 2014: 16), what is new is the mobility and complexity of these emerging constellations of power and violence, bringing together state agencies, private military forces, criminal gangs operating as de facto corporations, oil extraction companies and global finance. ${ }^{3}$

What is new from our point of view as critics of crime fiction is the emergence of hybrid forms capable of mapping these complexities. For example, one result of this bleeding of crime into war and war into crime is the emergence of drug war fiction as an amalgam of crime and war fiction, a move with important consequence for our understanding of jurisdiction and also ethics. In its commonest iteration, the crime story has been premised on the activities of a lone investigator working within a clearly delimited jurisdiction or territory (e.g. city, state) and even when their ethics become compromised by the fraught situation 
being investigated, the solution, however partial, can be achieved within these limits (Pepper, 2016). In doing so, it presupposes a distinction between a set of domestic policing activities and external security initiatives pursued by a mix of intelligence and military personnel. At the level of genre, Winslow's novels undo these distinctions and the archetypes upon which they depend. For example, what is the crime being investigated? The import of illegal narcotics from Mexico in the US? The thousands of unsolved murders on both sides of the border but especially in Mexico? The complicity of various figures in the Mexican and US judiciary, military, police and government with the cartels? The privileging of a system of social and economic organisation that safeguards capital accumulation over human lives? To bring a case, under law, against these infractions - against even the 'top down' figures we see in The Border - is impossible. As a prosecutor tells Keller, 'I can't bring a case I don't think I can win' (2019: 597). Meanwhile, the militarization of criminal justice in The Cartel, for example, where 'the DEA is assisting the Mexican military in targeting top narcos for "arrest" that are often executions' (2015: 392) and where the 'U.S. intelligence apparatus in Mexico has expanded dramatically' (2015: 521) results only in further bloodletting: 'Another pitched battle was fought in Zacatecas, where more than 250 Zetas fought the FES in a give-hour running gunfight.' (2015: 521). In The Border, Winslow makes an implicit connection between the violence in Mexico which 'has just gone on and on and on' and the fatal shooting of 'eighteen-year-old African-American Michael Brown' by a 'cop in Ferguson, Missouri' which triggers 'days of violent rioting' and further police violence (2019: 134). Domestic policing initiatives which assume a military dimension (e.g. Kevlar-armed police being 'dispatched' into 'unsafe' parts of the US city to 'take back' the streets) are now as familiar in 'real life' (e.g. Ferguson) as they are in crime fiction (e.g. The Wire) [see Deer, 2016].

There are some knotty genre-related issues at stake in this slippage of war into crime and crime into war, not least the question of justice which has always been central to crime 
fiction. If justice is hard to come by in the realm of the traditional crime story - where a policing mandate is executed within a specific territory and jurisdiction - it is impossible in the more open-ended realm of Winslow's drug war fiction, even when it is individualised ('top narcos' targeted for 'execution'). In a wider political sense, the focus on the intersection of crime and war or on what Bigo calls 'the möbius ribbon of internal and external security(ies)' (200: 91), where the domains of policing and military converge, permits a thoroughgoing critique of the territorial and jurisdictional limits of sovereignty. But in a generic sense, the critical potential is just as far-reaching. What kind of justice is possible in a context where the forces of the state and the cartels are joined? Where state and cartel militarisation is at once at the service of criminal enterprise (which is also presented as capitalist enterprise) and yet at the same time a form of criminalisation (insofar as it kills mostly poor people)? Where the criminalisation of the military and the militarisation of criminal justice make it hard, if not impossible, to make ethical prognostications about good and bad outcomes? If the result is a kind of 'epistemic murk' that John and Jean Comaroff maintain is symptomatic of crime fiction and a social order 'ever more impossible to apprehend' and violence 'ever more endemic, excessive [and] transgressive' (2004: 803), then it is a murk we should welcome rather than condemn - because it refuses totality, both in an ethical or moral sense (i.e. no one is wholly good or bad) and in a systemic sense (i.e. systems cannot be discerned as totalities and are prone to glitches or breakdown).

\section{Conclusion}

To further confuse the Comaroffs' analogy, I want to claim that Winslow's drug war fiction does allow us to see some important things through the murk. There are two particular aspects of this critical insight I would like to develop in my conclusion. Firstly, and perhaps because the subject itself is hard to grasp (what kind of fiction is it and what are its generic and 
territorial limits?), I want to suggest that Winslow's novels are exercised by this same spirit of enquiry; i.e. wanting to find a new, expansive form appropriate to the task of capturing a stillemerging reality. In one sense, and thinking about the serial dimension of 'complex' TV series like The Wire, where each new season revealed some new aspect of the world, and given that the 'war on drugs' has no obvious end-point, one wonders whether The Border really marks some definitive end-point, i.e. where, as Keller puts it at the end of The Border, while testifying to a Senate hearing, 'I have, sadly, come to the conclusion that we have fought the wrong war, and that it must come to an end' (707). In another ending, Keller recognises that the 'chaos and violence go on' (716) and that it is a misnomer to think of narrative as teleological; i.e. as unfolding towards some definitive end-point. For Nico, the 'ending' is a return to the 'beginning' insofar as his arrest for possession of cocaine results in his likely extradition back to Guatemala and 'El Basurero...the garbage dump' (702).

Secondly, following on from this claim about narrative expansiveness and openendedness, I want to underscore the significance of a wider spatial or geographical lens. It may be impossible to map totality in a geographical or narrative sense, but there are connections which are at once contingent and deterministic (e.g. Nico fleeing Guatemala City to escape Calle 18 only, by chance(?), to join another branch of Calle 18 when he arrives in New York). More particularly these connections demonstrate how the conditions of being poor and disposable in Guatemala or Mexico are not dissimilar to being poor and disposable in New York and how both conditions are constitutive of the same cycles of consumption and accumulation that create enormous wealth for traffickers, financiers and property developers in Mexico and the US, as Marx first observed a century and a half ago: 'Accumulation of wealth at one pole is, therefore, at the same time an accumulation of misery... at the opposite pole (see Harvey, 2001: 27). But in narrative, as in life, those, like Nico, who have to negotiate their 'accumulation of misery' do not so merely as victims - as fully determined by 
Agamben's violence of the exception. Rather it is their refusal to succumb and their determination that lives longest in our minds, even if they are unaware of their place in the wider system: Nico running for La Bestia ('You're fast. You're Nico Rápido, you can do this') [2019: 337]; Nico Rápido making 'his reappearance in the court (in the Southern Virginia Youth Detention Facility) as 'he cuts and slashes, dribbles around and through the opposition' (2019: 507); and Nico Rápido 'the best cell-phone booster Calle 18 ever had because he was small and fast' (2019: 655). If Nico and Chuy are glitches in the system, then we should not get too carried away by their subversive potential. As Berlant explains, 'if a glitch has made apparent these conditions of disrupted jurisdiction, resource and circulation, a disruption in rules and norms is not the same as the absence or defeat of structure' (2016:394). Which is another way of saying the 'war on drugs' as system is dead, long live the 'war on drugs as system.'

\section{NOTES}

${ }^{1}$ In fact, based on Jameson's collection of essays about Raymond Chandler, The Detections of Totality (2016), there is more than unites than separates our respective positions. In these essays, Jameson proposes that against the imperatives of totality, Chandler gives us fragmented pictures of, and sideways glances at, the mundanities of everyday life.

${ }^{2}$ Gulddal, King and Rolls usefully point out that "'pure" examples of certain crime fiction formats are arguably rare [and] that in recent years, hybrid forms, including those that result from transnational mobility, have become the norm' (forthcoming).

${ }^{3}$ These are what Mbembe refers to as 'war machines' have 'the feature of a political organization and a mercantile company' and 'rapidly become highly organized mechanisms of predation' $(2003: 32,34)$ across diffuse territories.

\section{WORKS CITED}

Agamben, Giorgio. Homo Sacer: Sovereign Power and Bare Life. Stanford: Stanford University Press, 1998.

---.Means without End: Notes on Politics. Translated by Vincenzo Binetti and Cesare Casarino. Minnesota UP, 2000.

Bayard, Pierre. Who Killed Roger Ackroyd?: the murderer who eluded Hercule Poirot and deceived Agatha Christie. London: Fourth Estate, 2000.

Berlant, Lauren. Cruel Optimism. Duke UP, 2012. 
---. 'The commons: Infrastructures for troubling times.' Environment and Planning D: Society and Space, 34: 3 (2016), 393-419.

Bigo, Didier. 'Liaison Officers in Europe: New Officers in the European Security Field.' J.W.E. Sheptycki, editor, Issues in Transnational Policing. Routledge, 2000. 67-99

Comaroff, Jean and John. 'Criminal Obsessions, after Foucault: Postcoloniality, Policing and the Metaphor of Disorder.' Critical Inquiry, 30:4, 2004. 800-824.

Deer, Patrick. 'Mapping Contemporary American War Culture.' College Literature: A Journal of Critical Literary Studies, 43:1, 2016. 48-90.

DeFino, Dean J. The HBO Effect. Bloomsbury, 2014.

Dimock, Wai-Chee and Buell, Lawrence, eds. Shades of the Planet: American Literature as World Literature. Princeton UP, 2007.

Dowdy, Michael. Broken Souths: Latina/o Poetic Responses to Neoliberalism and Globalization. U of Arizona P, 2013.

Frazer, Elizabeth and Kimberly Hutchings, 'Remnants and Revenants: Politics and Violence in the work of Agamben and Derrida.' British Journal of Politics and International Relations 13:2 (2011), 127-144.

Gulddal, Jesper, Stewart King and Alastair Rolls. Criminal Moves: Modes of Mobility in Crime Fiction. Liverpool UP, 2019.

Harvey, David. Spaces of Hope. Edinburgh UP, 2001.

Holloway, David. 9/11 and the War on Terror. Edinburgh UP, 2008.

Jameson, Fredric. Postmodernism or, The Cultural Logic of Late Capitalism. Verso, 1992.

---. The Geopolitical Aesthetic: Cinema and Space in the World System. Indiana UP, 1995.

---. Raymond Chandler: The Detections of Totality. Verso, 2016.

Kraniauskas, John. 'Elasticity of Demand: Reflections on The Wire.' Liam Kennedy and Stephen Shapiro, editors, The Wire: Race, Class, Gender. UP Michigan, 2012. 170192.

Mbembe, Achille. 'Necropolitics.' Translated by Libby Meintjes. Public Culture, 15:1 (2003), $11-40$.

Miller, D.A. Narrative and its Discontents: Problems of Closure in the Traditional Novel. Princeton: Princeton University Press, 1981.

Mittell, Jason. Complex TV: The Poetics of Contemporary Television Storytelling. New York: New York University Press, 2015.

Paley, Dawn. Drug War Capitalism. AK Press, 2014.

Pansters, Wil, Benjamin Smith and Peter Watt, editors. Beyond the Drug War in Mexico: Human Rights, the Public Sphere and Justice. Routledge, 2018.

Pepper, Andrew. Unwilling Executioner: Crime Fiction and State. Oxford UP, 2016.

Reising, Russell. Loose Ends: Closure \& Crisis in the American Social Text. Durham and London: Duke University Press, 1996.

Rodríguez, Sergio Gonzáles. The Femicide Machine. Translated by Michael ParkerStainback. Semiotext(e), 2012.

Seltzer, Mark. True Crime: Observations on Violence and Modernity. Routledge, 2007.

Toscano, Alberto and Kinkle, Jeff. Cartographies of the Absolute. Zero Books, 2015.

Valencia, Sayak. Gore Capitalism. Translated John Pluecker. Semiotext(e), 2018.

Winslow, Don. The Power of the Dog. Vintage, 2006.

---. The Cartel. Alfred A. Knopf, 2015.

---. The Border. Alfred A. Knopf, 2019. 